\title{
Tylosema esculentum (Marama) Tuber and Bean Extracts Are Strong Antiviral Agents against Rotavirus Infection
}

\author{
Walter Chingwaru, ${ }^{1}$ Runner T. Majinda, ${ }^{2}$ Sam O. Yeboah, ${ }^{2}$ Jose C. Jackson, ${ }^{3}$ \\ Petrina T. Kapewangolo, ${ }^{4}$ Martha Kandawa-Schulz, ${ }^{4}$ and Avrelija Cencic ${ }^{1,5}$ \\ ${ }^{1}$ Department of Microbiology, Biochemistry, Molecular Biology and Biotechnology, Faculty of Agriculture and Life Sciences, \\ University of Maribor, Pivola 10, 2311 Hoče, Slovenia \\ ${ }^{2}$ Department of Chemistry, University of Botswana, Private Bag 0022 Gaborone, Botswana \\ ${ }^{3}$ Research and Development Office, University of Botswana, Private Bag 0022 Gaborone, Botswana \\ ${ }^{4}$ Department of Chemistry and Biochemistry, University of Namibia, 340 Mandume Ndemufayo Avenue Pionierspark, \\ Private Bag 13301 Windhoek, Namibia \\ ${ }^{5}$ Faculty of Medicine, University of Maribor, Slomškov trg 15, 2000 Maribor, Slovenia
}

Correspondence should be addressed to Avrelija Cencic, avrelija.cencic@uni-mb.si

Received 16 April 2010; Revised 1 December 2010; Accepted 9 January 2011

Copyright (๑) 2011 Walter Chingwaru et al. This is an open access article distributed under the Creative Commons Attribution License, which permits unrestricted use, distribution, and reproduction in any medium, provided the original work is properly cited.

Tylosema esculentum (marama) beans and tubers are used as food, and traditional medicine against diarrhoea in Southern Africa. Rotaviruses (RVs) are a major cause of diarrhoea among infants, young children, immunocompromised people, and domesticated animals. Our work is first to determine anti-RV activity of marama bean and tuber ethanol and water extracts; in this case on intestinal enterocyte cells of human infant (H4), adult pig (CLAB) and adult bovine (CIEB) origin. Marama cotyledon ethanolic extract (MCE) and cotyledon water extract (MCW) without RV were not cytotoxic to all cells tested, while seed coat and tuber extracts showed variable levels of cytotoxicity. Marama cotyledon ethanolic and water extracts (MCE and MCW, resp.) ( $\geq 0.1 \mathrm{mg} / \mathrm{mL}$ ), seed coat extract (MSCE) and seed coat water extract (MSCW) (0.01 to $0.001 \mathrm{mg} / \mathrm{mL}$ ), especially ethanolic, significantly increased cell survival and enhanced survival to cytopathic effects of RV by at least $100 \%$ after in vitro co- and preincubation treatments. All marama extracts used significantly enhanced nitric oxide release from H4 cells and enhanced TER $\left(\Omega / \mathrm{cm}^{2}\right)$ of enterocyte barriers after coincubation with RV. Marama cotyledon and seed coat extracts inhibited virion infectivity possibly through interference with replication due to accumulation of nitric oxide. Marama extracts are therefore promising microbicides against RV.

\section{Introduction}

Tylosema esculentum (Burch.) (marama) A. Schreib. (family Caesalpiniaceae or Leguminosae) [1], also known as "the Green Gold of Africa," is a creeping plant found in the southern parts of Africa, namely South Africa, Namibia, and Botswana. Tylosema esculentum bean and tuber extracts have been used in traditional African medicine to treat diarrhoea and for general upkeep of human health [2]. Only little chemical characterization has been done to date on the $T$. esculentum plant. Research on chemical and health benefits of T. esculentum plant is part of an ongoing research project under EU-INCO Marama II FP6 programme (contract number 032059).
Various bioactive constituents are expected to be present in T. esculentum plant. These may include phenolic constituents, carbohydrates, and certain fatty acids, among many components. Large amounts of gallic acid have been detected in T. esculentum plant [3]. Gallic acid esterifies with glucose, the resultant hydrolysable tannins (HTs), secondary metabolites widely distributed in the plant kingdom, are known to be effective antagonists against viruses [3]. Tylosema esculentum tubers contain yet to be determined phenolics [3]. High amounts of phytosterols have also been detected in T. esculentum oil (about $75 \%$ of all phytosterols being 4-desmethylsterols and about $15.72 \%$ of the total being 4,4-dimethylsterols) [4]. 


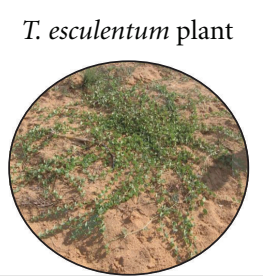

T. esculentum parts
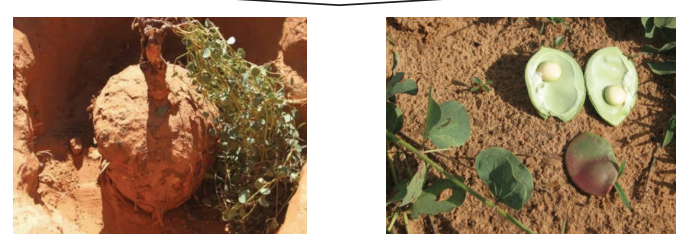

Antiviral mechanisms
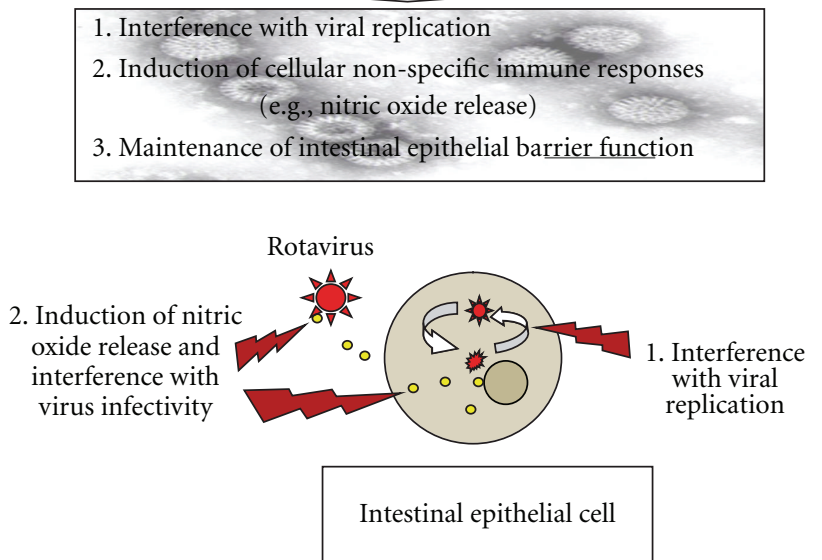

3. Strengthening of intestinal epithelial barrier function $\left(\mathrm{TER}-\Omega / \mathrm{cm}^{2}\right)$

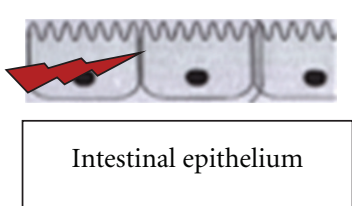

FIgURE 1: Proposed mechanisms of antirotaviral activity of T. esculentum plant parts.

Rotavirus (RV) infections are a major cause of acute gastroenteritis in infants and young children, accounting for about 611,000 deaths each year worldwide, mostly in developing countries [5]. Rotavirus is also an important pathogen in many agricultural species, inducing serious diarrhoeal diseases in neonatal and postweaning pigs and calves [6-8]. Rotavirus infection is limited to the mature enterocytes of the tips of the intestinal villi of humans, domestic animals, and mice, leading to severe gastroenteritis in the young [9]. Some strains of bovine and human RV have high sequence homology and interspecific infectivity, both implying phylogenetic relatedness [10,11]. Previous in vitro tests of the bovine RF strain of RV on human, pig, chicken, and goat intestine epithelial cells in our laboratory have shown interspecific infectivity of rotavirus [12], and, therefore, the bovine strain of rotavirus was used to infect human and pig intestinal cells in the current study.
It is known that infection of intestinal epithelial cells with RV causes disruption of tight junctions and loss of transepithelial resistance (TER), even in the absence of cell death [13]. Loss of TER involves alteration of tight junction proteins, mainly claudin-1, occludin, and ZO-1 as determined in human small intestine carcinoma cells (Caco2) [13], although use of cancer cells for such mechanistic studies is not appropriate. Rotavirus infection is also associated with increased production of lactate, decreased mitochondrial oxygen consumption, and reduced cellular ATP, conditions known to reduce the integrity of epithelial tight junctions $[13,14]$.

While vaccines such as RataTeq and Rotatrix have been made available for prevention of RV infections [15, 16], their effectiveness remains to be verified [17]. Use of a few synthetic compounds against simian RV, such as ribavirin [18] and isoprinosine [19], and natural products against human and bovine RV [20], such as theaflavins, has been reported. Unfortunately, these compounds are not available for human use, which necessitates alternative methods to control RV infection [21]. A promising alternative strategy to reducing the burden of diarrhoea caused by RV may lie in identifying and developing costeffective nutritional or phytomedical solutions; which can be applicable especially in children and immunocompromised persons.

With this information, and related empirical supporting information from other legume plants, it was hypothesised that T. esculentum bean and tuber extracts can inhibit RV infection. The proposed mechanisms of antiviral effects of T. esculentum are summarised in Figure 1. It was herein projected that extracts from T. esculentum beans and tubers can be included in various medicine mixtures or whole beans and tubers be used as functional foods, with the aim to combat diarrhoea caused by RV.

In this study we sought to examine the antirotaviral activity of water and ethanol extracts from bean cotyledons and bean seed coats and water extracts from $T$. esculentum tubers by investigating their ability to increase survival of human foetal, pig, and calf intestinal epithelial cells.

\section{Materials and Methods}

2.1. Collection of T. esculentum Bean and Tuber Samples. All research on the plant was done with full authorisation granted to Marama II INCO (EU-FP6) research programme. T. esculentum (marama) bean samples were obtained in Botswana in 2005 and 2007, and the T. esculentum tuber sample was obtained in Botswana in 2007. Seeds were stored in plastic bags at room temperature until time for extraction. The T. esculentum tuber (approximately $20 \mathrm{~kg}$ wet mass) was dug out from a site in Jwaneng, then ground and air-dried at University of Botswana, and then further ground to fine powder before the extraction was done at University of Maribor, Slovenia. A voucher specimen of T. esculentum plant is kept in the Namibian National Herbarium (collecting number: GM 1063 and herbarium number: 59520). 
TABLE 1: Yields of T. esculentum bean and tuber extracts (mg of extract per gram of plant material).

\begin{tabular}{lc}
\hline Extract & Yield $(\mathrm{mg} / \mathrm{g})$ \\
\hline MCE & 100 \\
MSCE & 100 \\
MTW & 26.19 \\
MCW & 19.55 \\
MSCW & 10.78 \\
\hline
\end{tabular}

MCE: T. esculentum bean cotyledon ethanolic extract, MSCE: T. esculentum bean husk ethanolic extract, MTW: T. esculentum tuber water extract, MSCW: T. esculentum bean husk water extract, and MCW: T. esculentum bean cotyledon water extract.

\subsection{Extraction of T. esculentum}

2.2.1. Water Extraction. Shade-dried bean and tuber materials ( $20 \mathrm{~g}$ each) were ground to fine powder, the volume was adjusted to $200 \mathrm{~mL}$ by addition of distilled water, and left for 16 hours at room temperature. The mixture was blended to mix and then centrifuged at $4000 \mathrm{rpm}$ (2050 g) for 30 minutes using a Sorval Evolution RC Superspeed centrifuge (Thermo, USA) at $4^{\circ} \mathrm{C}$. The supernatant was filtered using $0.45 \mu \mathrm{m}$ pore filters (Millipore, Ireland) and then stored at $-20^{\circ} \mathrm{C}$ until use. The T. esculentum water extracts, namely, seed coat water extract (MSCW), cotyledon water extract (MCW), and tuber water extract (MTW), were evaporated with a Soxhlet apparatus (Carl Roth WHLG2/ER-Serie, Karlsruhe, Germany) and then stored at $-20^{\circ} \mathrm{C}$ until use. The following water extracts from T. esculentum beans and tuber were obtained: tuber water extract (MTW), cotyledon water extract (MCW), and seed coat water extract (MSCW) (Table 1).

2.2.2. Ethanolic Extraction Procedure. Crude bean ethanolic extracts were prepared as described by Bolling and Parkin [22]. Briefly, 1 litre of ethanol was used to extract $100 \mathrm{~g}$ of shade-dried T. esculentum bean at $78^{\circ} \mathrm{C}$ using a Soxhlet apparatus (Carl Roth WHLG2/ER-Serie, Karlsruhe, Germany) for extraction. The evaporation procedure ensured the exclusion of ethanol from the extracts; the resultant extract was a thick paste; these extracts were labelled MSCE (seed coat ethanolic extract) and MCE (cotyledon ethanolic extract) and stored at $-20^{\circ} \mathrm{C}$ until use. Ethanolic extracts are known to contain mainly lipids and other ethanol soluble contents such as isoflavones [22-24]. The following extracts from T. esculentum beans and tuber were obtained: cotyledon ethanolic extract (MCE) and seed coat ethanolic extract (MSCE) (Table 1).

Below are the yields of each extract $(\mathrm{mg})$ per $\mathrm{g}$ of $T$. esculentum bean and tuber material used.

\subsubsection{Cells and Viral Strains}

Cell cultures. The following cell lines were used in the antiviral tests: human foetal small intestine epithelial cells (H4) [25] (a generous gift from Dr. Tor Savidge, USA), pig small intestine epithelial cells (CLAB), isolated in our laboratory
[26] and maintained by University of Maribor, Slovenia, and bovine calf small intestine epithelial cells (CIEB), isolated in our laboratory [26] and maintained by University of Maribor, Slovenia. The cells were grown in advanced Dulbecco's Modified Eagle's Medium (DMEM) (SigmaAldrich, Grand Island, USA), supplemented with 10\% foetal calf serum (Cambrex, Verviers, Belgium), L-glutamine ( $2 \mathrm{mmol} / \mathrm{L}$, Sigma), penicillin (100 units/mL, Sigma), and streptomycin ( $1 \mathrm{mg} / \mathrm{mL}$, Fluka, Buchs, Switzerland). Cell lines were routinely grown in $25 \mathrm{~cm}^{2}$ culture flasks (Corning, New York, USA) at $37^{\circ} \mathrm{C}$ in a humidified atmosphere of $5 \% \mathrm{CO}_{2}$ and $95 \%$ air until confluent monolayers attained. Culture medium was changed routinely.

2.2.4. Virus Propagation. An RF RV strain, as previously described in $[27,28]$, was used in all tests. Confluent cultures (in $25 \mathrm{~cm}^{2}$ Corning flasks) of $\mathrm{H} 4, \mathrm{CLAB}$, and CIEB cells were washed twice in single strength phosphate buffer $(1 \times$ PBS $)$ to remove the foetal bovine serum (FBS) before infection with RV (previously passaged 5 times on H4, CLAB, and CIEB cells in rotation; at $1 \times 10^{7.5} / \mathrm{mL} \mathrm{TCID}_{50}$ in the presence of $1 \mu \mathrm{g}$ of trypsin (Sigma Chemical Co., St. Louis, Mo) per $\mathrm{mL}$. After a 1 -hour adsorption period at $37^{\circ} \mathrm{C}$, DMEM, containing 0.5\% FBS (Sigma Chemical Co., St. Louis, Mo.) and $1 \mu \mathrm{g}$ of trypsin per $\mathrm{mL}$, was added to each flask. The flasks with cells were incubated for 24 to $48 \mathrm{~h}$ at $37^{\circ} \mathrm{C}$, under $10 \% \mathrm{CO}_{2}$ until cytopathic effect (CPE) was observed by microscopy. When the cells showed extensive cytopathic degeneration, the flasks with cells and virus were subjected to two freeze-thaw cycles to detach and break the cells. The supernatant fluids containing detached cells and extracellular virus were removed, and then the cellular debris was removed by centrifugation at $3500 \mathrm{~g}$ for $10 \mathrm{~min}$. Virus was stored at $-70^{\circ} \mathrm{C}$ until time for tests.

Tissue culture infective dose $\left(\mathrm{TCID}_{50}\right)$ was determined using the method of Reed and Muench [29], as previously described in [30]. Clarified supernatants of RV titrating $1 \times 10^{7.5} \mathrm{TCID}_{50} / \mathrm{mL}$ (tissue culture infectious dose $50 \%$, $\mathrm{TCID}_{50}$ ) were subsequently used for the antiviral tests with T. esculentum extracts. Similar TCID ${ }_{50}$ values were obtained by Bae et al. [31] $\left(1.27 \times 10^{6}\right.$ per $\left.\mathrm{mL}\right)$ when they titrated RV on Macacus Rhesus monkey kidney cells (MA104).

2.2.5. Studies on Cytotoxicity of T. esculentum on Intestinal Epithelial Cells. Tylosema esculentum extracts were dissolved in DMEM (Sigma-Aldrich, Grand Island, USA), supplemented with $10 \%$ foetal calf serum (Cambrex, Verviers, Belgium), L-glutamine ( $2 \mathrm{mmol} / \mathrm{L}$, Sigma), penicillin (100 units/mL, Sigma), and streptomycin $(1 \mathrm{mg} / \mathrm{mL}$, Fluka, Buchs, Switzerland) using a rotary magnetic stirrer (Yellowline, BigSquid, Kika-Werke GMBH \& Co, Germany). As control, DMEM (Sigma-Aldrich, Grand Island, USA), supplemented with 10\% foetal calf serum (Cambrex, Verviers, Belgium), L-glutamine ( $2 \mathrm{mmol} / \mathrm{L}$, Sigma), penicillin (100 units/mL, Sigma), and streptomycin $(1 \mathrm{mg} / \mathrm{mL}$, Fluka, Buchs, Switzerland), was used. The extracts were added diluted 10-fold to monolayers of cells in 96 well plates, then maintained at $37^{\circ} \mathrm{C}$ in a humidified atmosphere of 
TABLE 2: Selected concentrations of Tylosema esculentum extracts ( $\mathrm{IC}_{50}$ and below).

\begin{tabular}{lc}
\hline Extract & $\begin{array}{c}\text { Concentration of marama used in tests } \\
(\mathrm{mg} / \mathrm{mL} \text { of solution }) /(\mathrm{mg} / \mathrm{g} \text { of plant material })\end{array}$ \\
\hline \multirow{2}{*}{ MCE } & $1 / 0.1$ \\
& $0.1 / 0.01$ \\
MSCE & $0.1 / 0.01$ \\
& $0.01 / 0.001$ \\
MTW & $0.1 / 0.01$ \\
& $0.01 / 0.001$ \\
MCW & $2 / 0.2$ \\
& $0.2 / 0.02$ \\
MSCW & $0.01 / 0.001$ \\
\end{tabular}

MCE: T. esculentum bean cotyledon ethanolic extract, MSCE: T. esculentum bean husk ethanolic extract, MTW: T. esculentum tuber water extract, MSCW: T. esculentum bean husk water extract, and MCW: T. esculentum bean cotyledon water extract.

$5 \% \mathrm{CO}_{2}$ and $95 \%$ air for $24 \mathrm{~h}$. Following incubation, cells were carefully rinsed with PBS to remove T. esculentum extracts and other debris. Upon washing, plates were stained with $0.01 \%$ crystal violet for 5 minutes and then rinsed with water. Plates were then dried, and then crystal violet incorporated in viable cells was resuspended with $10 \%$ acetic acid ( $100 \mu \mathrm{L}$ per well). Photometric quantification of crystal violet previously retained in living cells was done at $595 \mathrm{~nm}$ with a microplate reader (Multiscan, Finland) as described by Agelis et al. [32]. After this test for cytotoxicity, certain concentrations of T. esculentum extracts were selected for antiviral tests as shown in Table 2.

2.2.6. Studies on Protection of Intestinal Epithelial Cells against $R V$ with T. esculentum Extracts. Tylosema esculentum ethanolic extracts, namely, seed coat ethanolic extract (MSCE) and cotyledon ethanolic extract (MCE) were dissolved using a rotary magnetic stirrer (Yellowline, BigSquid, Kika-Werke GMBH \& Co, Germany) in DMEM (Sigma-Aldrich, Grand Island, USA), supplemented with $10 \%$ foetal calf serum (Cambrex, Verviers, Belgium), L-glutamine $(2 \mathrm{mmol} / \mathrm{L}$, Sigma), penicillin (100 units/mL, Sigma), and streptomycin $(1 \mathrm{mg} / \mathrm{mL}$, Fluka, Buchs, Switzerland). Rotavirus at $1 \times 10^{7.5} / \mathrm{mL}$ TCID $_{50}$ was combined with concentrations of T. esculentum extracts (see Table 2). As controls, DMEM (Sigma-Aldrich, Grand Island, USA), supplemented with $10 \%$ foetal calf serum (Cambrex, Verviers, Belgium), Lglutamine $(2 \mathrm{mmol} / \mathrm{L}$, Sigma), penicillin (100 units $/ \mathrm{mL}$, Sigma), and streptomycin (1 mg/mL, Fluka, Buchs, Switzerland), dilutions of Combivir GlaxoSmithKline- $150 \mathrm{mg}$ lamivudine and $300 \mathrm{mg}$ zidovudine (AZT) as antiviral agent as described by Agelis et al. [32, 33] and T. esculentum extract at below $\mathrm{IC}_{50}$ concentrations and RV solutions at $1 \times 10^{7.5} / \mathrm{mL} \mathrm{TCID}_{50}$ were separately used. The plant extract and virus, Combivir, and virus mixtures were added to monolayers of cells in 96-well plates and then maintained at $37^{\circ} \mathrm{C}$ in atmosphere of $5 \% \mathrm{CO}_{2}$ for $24 \mathrm{~h}$.
Cytopathic effects of RV alone and in coculture with T. esculentum extracts or Combivir added at $0.75 \mathrm{mg} / \mathrm{mL}$ \{modified from Agelis et al. [33]\} on cell monolayers after treatment as listed above were measured after 24-hour coincubation of cell monolayers $\left(1 \times 10^{6}\right.$ cells $\left./ \mathrm{mL}\right)$ at $37^{\circ} \mathrm{C}$ in atmosphere of $5 \% \mathrm{CO}_{2}$. It was previously shown that $T$. esculentum extracts alone were not cytotoxic at the concentrations used in these tests; hence the observed reduction in survival of cells upon coincubation of extract RV solutions was attributed mainly to the virus. Following incubation, relative viability of cells was determined photometrically in terms of amount of crystal violet incorporated in viable cells as described previously.

2.2.7. Studies on Effect of Coincubation of Rotavirus with T. esculentum Extracts on Monolayer Polarity (TER) (\% $\Omega$ ) of Human Small Intestine Epithelial Cells (H4) over Time. Human small intestinal epithelial cells (H4) were introduced into inserts in 12-well plates (Corning Transwell, $0.4 \mu \mathrm{m}$ pore size, New York, USA) at concentration of $1 \times 10^{6}$ cells $/ \mathrm{mL}$. Transepithelial resistance $\left(\mathrm{TER}-\Omega / \mathrm{cm}^{2}\right.$ ) was measured periodically using Millicell-ERS Electrical Resistance System (Millipore, Bedford, USA) until values of about $1000 \Omega / \mathrm{cm}^{2}$ were attained, such high values indicating maximum attainable polarity in $\mathrm{H} 4$ cells, as previously determined (results not shown). Rotavirus suspensions (at $1 \times 10^{7.5} / \mathrm{mL} \mathrm{TCID}_{50}$ ) were mixed with $T$. esculentum extracts at below their predetermined $\mathrm{IC}_{50}$ concentrations (Table 2) and then introduced onto $\mathrm{H} 4$ monolayers in insert wells. Tylosema esculentum extracts diluted in DMEM, DMEM alone, and Combivir diluted in DMEM were introduced as respective controls. The effect of the extracts on the cell polarity was evaluated by measurement of transepithelial electrical resistance (TER) as previously described in [34]. TER values of monolayers exposed to combinations of marama/Combivir treatments, DMEM, and RV controls were plotted.

2.2.8. Inhibition of Virion Infectivity Studies. Rotavirus (at $1 \times 10^{7.5} / \mathrm{mL} \mathrm{TCID}_{50}$ ) was incubated with $T$. esculentum water and ethanolic extracts at room temperature for $1 \mathrm{~h}$. Following the incubation, dilutions of the incubated virus were added to CLAB, CIEB, and $\mathrm{H} 4$ cell monolayers in 96well plates and then incubated for $1 \mathrm{~h}$ at $37^{\circ} \mathrm{C}$ in a humidified atmosphere of $5 \% \mathrm{CO}_{2}$ and $95 \%$ air, after which the unattached virus and the extracts were washed off with PBS. DMEM (Sigma-Aldrich, Grand Island, USA), supplemented with $10 \%$ foetal calf serum (Cambrex, Verviers, Belgium), L-glutamine $(2 \mathrm{mmol} / \mathrm{L}$, Sigma), penicillin (100 units $/ \mathrm{mL}$, Sigma), and streptomycin $(1 \mathrm{mg} / \mathrm{mL}$, Fluka, Buchs, Switzerland), was then introduced on the cells and then incubated for $24 \mathrm{~h}$ at $37^{\circ} \mathrm{C}$ in atmosphere of $5 \% \mathrm{CO}_{2}$ until viral cytopathic effects were observed in control wells. Cell viability was then determined with quantification of crystal violet as described previously. As control, viral only, T. esculentum only and cell culture medium only treatments were plated onto the epithelial cells. Relative protection by T. esculentum extracts against RV infection was determined by crystal 
violet staining. Percent (\%) inhibition of RV by T. esculentum extracts as shown by survival of epithelial cells was calculated, thus

(average OD of wells containing RV preincubated with T. esculentum extracts minus $O D$ of wells containing $\mathrm{RV}$ only) divided by average OD of wells containing RV only multiplied by $100 \pm \%$ average standard deviation. An indication of level of significance $\left(^{*}\right)$ as tested using Statsoft Statistica software $(P<.05)$ was given.

Tests were done in triplicate wells. Tylosema esculentum extracts used were as follows: cotyledon ethanolic extract (MCE), seed coat ethanolic extract (MSCE), tuber water extract (MTW), cotyledon water extract (MCW), and seed coat water extract (MSCW). Tylosema esculentum extracts were introduced at and below $\mathrm{IC}_{50}$ or at 1 and $0.1 \mathrm{mg} / \mathrm{mL}$ of MCE (the highest concentration of MCE was not cytotoxic).

2.2.9. Total Nitric Oxide (NO) Release from $\mathrm{H} 4$ and $C L A B$ Cells after Exposure to T. esculentum Extracts. Release of NO after cell exposure to T. esculentum extracts was detected using a microplate reader (Multiscan, Finland) at $540 \mathrm{~nm}$ after introduction of Griess reagent (Sigma, Germany) into supernatants after 24-hour incubation. Results were expressed as percent difference between nitric oxide release of test from control. Nitric oxide is proportional to the amount of nitrate accumulating in supernatants as shown by the change of colour at $540 \mathrm{~nm}$.

2.2.10. Correlation Testing. Correlation coefficients for data obtained on level of protection, nitric oxide release, and transepithelial resistance (TER) were calculated using Statsoft Statistica version 7 software.

\section{Results}

3.1. Rotavirus Has Dose-Dependent Cytopathic Effect on Intestinal Epithelial Cells. To determine concentration of RV in the stock solution, the method of Reed and Muench [29] was adopted with modifications. Titration results showed that the RV strain had high and variable but not cell-typespecific cytopathic effects on all the cells used (Figure 2). Rotavirus, when incubated without T. esculentum extracts on cells, showed dose-dependent cytopathic effect on human small intestine epithelial cells (H4 cells), pig small intestine epithelial cells (CLAB), and bovine calf small intestine epithelial cells (CIEB) (Figure 2). For subsequent antiviral testing an RV concentration at and/or below $1 \times 10^{7.5} / \mathrm{mL}$ TCID $_{50}$ was used to avoid cotoxicity with extracts.

3.2. Tylosema esculentum Extracts Increase Survival of Intestinal Epithelial Cells. Tylosema esculentum bean water and ethanolic extracts and T. esculentum tuber water extract were added on cell monolayers of CLAB, CIEB, and H4 cells at concentrations as shown in Table 2 and Figures 3 and 6 . Tylosema esculentum extracts, at the concentrations used, resulted in dose-dependent enhancement of the three types of cells. Exposure to Tylosema esculentum seed coat water and

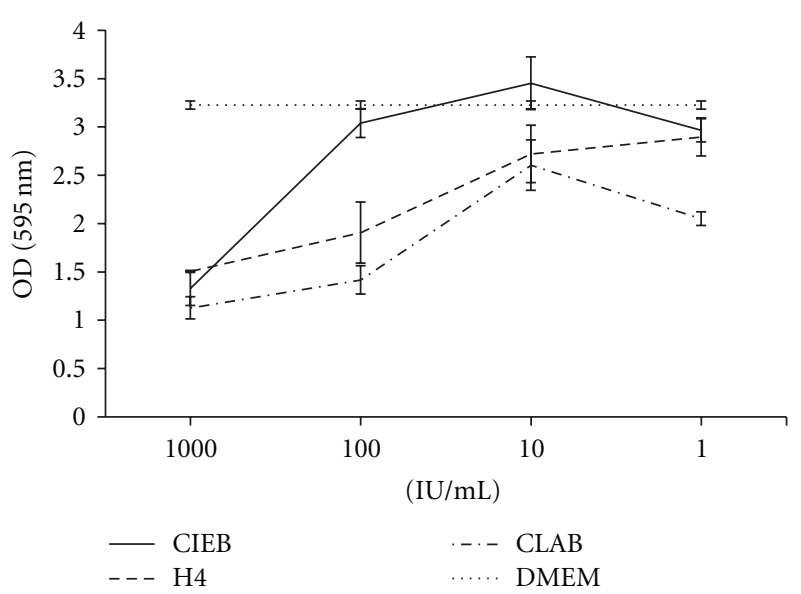

FIGURE 2: Dose-dependent cytopathic effect of rotavirus on bovine intestinal epithelial cells (CIEB), pig intestinal epithelial cells (CLAB), and human intestinal epithelial cells (H4). The graphs for cytopathic effect of rotavirus on the different cells are shown in terms of mean absorbance at each concentration \pm standard deviation at $595 \mathrm{~nm}$.

ethanolic extracts (MSCW and MSCE, resp.) generally led to enhanced survival of CLAB, CIEB, and H4 cells. This result could show that exposure to cotyledon extracts, besides the projected inhibition of RV cytopathic effects, could ensure cell survival.

3.3. Tylosema esculentum Extracts Protect Intestinal Epithelial Cells from Cytopathic Effects of RV. Tylosema esculentum extracts had the highest protection against RV cytopathic effects on bovine intestinal epithelial (CIEB) followed by pig intestinal epithelial cells (CLAB) and lastly human intestinal epithelial cells (H4) as shown in Figure 3. All T. esculentum extracts, especially cotyledon ethanolic extract (MCE), led to significant protection of CIEB, CLAB, and $\mathrm{H} 4$ cells from cytopathic effects of rotavirus. Tylosema esculentum seed coat water extract (MSCW) offered significant protection at the lowest concentration $(0.001 \mathrm{mg} / \mathrm{mL})$, making it the most potent extract. Tylosema esculentum cotyledon water extract (MCW) also led to highly significant protection of CLAB cells. There was largely highly significant protection of H4 cells exposed to MSCE, MSCW, MTW, and MCE. Combivir (control) was shown to have highly significant protection of cells against RV. Exposure to MCE was shown to enhance survival of CIEB cells (56\%) and H4 cells (275\%) more than that to Combivir. On H4, there was higher protection of cells with all extracts (91\%-275\%) depending on concentration than Combivir alone (Figure 3). Some extracts, mainly seed coat and cotyledon water and ethanolic, led to higher protection at concentrations lower than the determined $\mathrm{IC}_{50}$.

3.4. Coincubation of Rotavirus with T. esculentum Extracts Results in Dynamic Effects on Monolayer Polarity (TER) $\left(\% \Omega / \mathrm{cm}^{2}\right)$ of $H 4$ Cells over Time. Figure 4 shows changes in TER of H4 cells exposed to T. esculentum extracts, Combivir (AZT), or DMEM with and without RV over time. Over 


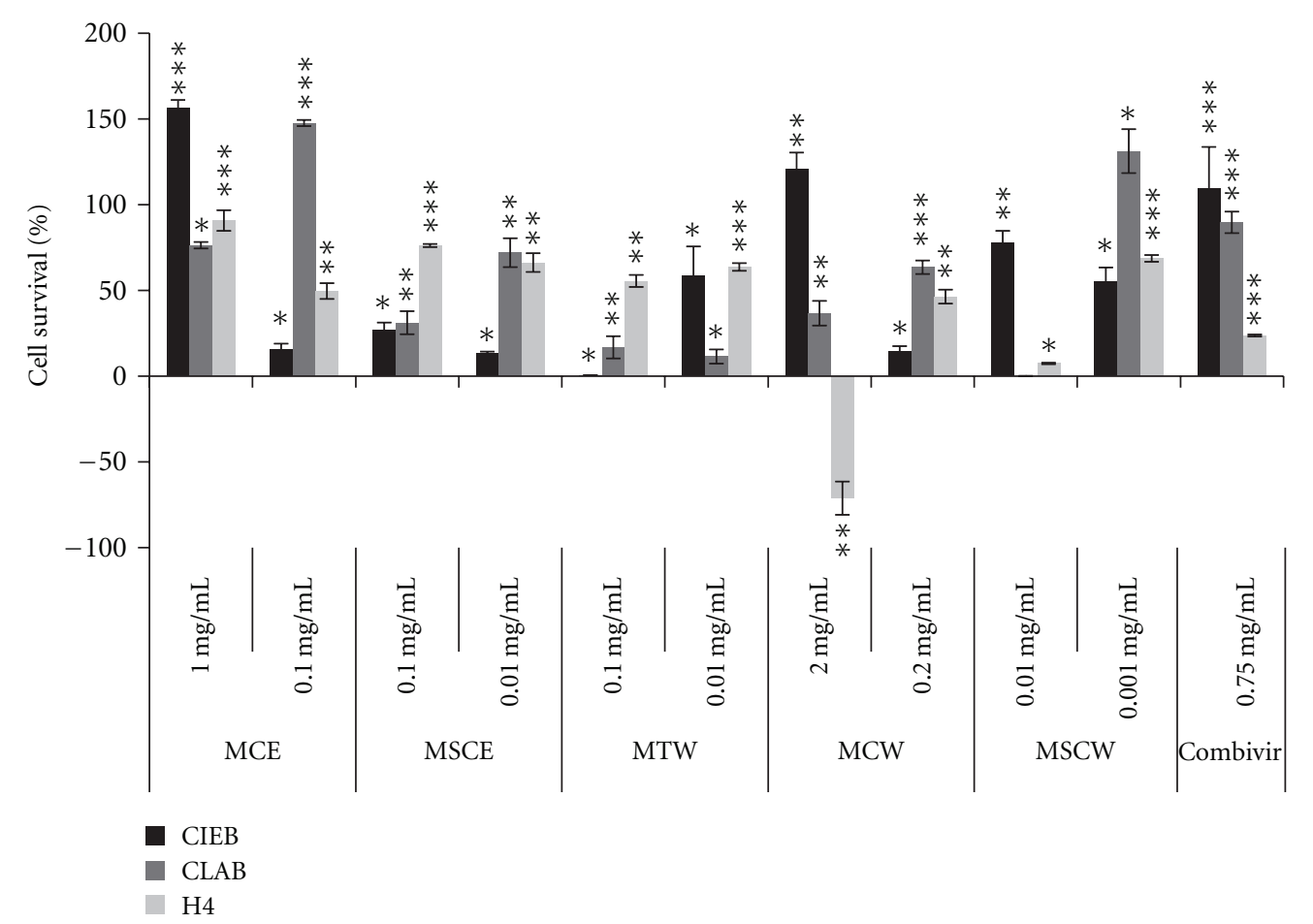

FIGURE 3: Survival of bovine intestinal epithelial cells (CIEB), pig intestinal epithelial cells (CLAB), and human intestinal epithelial cells (H4) from cytopathic effects of rotavirus in the presence of T. esculentum extracts. Shown above are bars of \% survival of epithelial cells $\{\%$ change in cell viability after coincubation of rotavirus with marama extracts compared to rotavirus only wells at OD $595 \mathrm{~nm} \pm \%$ standard deviation $\}$, respective levels of significance in terms of $T$ values $\left({ }^{*}\right) . T$ values were determined using Statsoft Statistica software $(P<.05)$. Tests were done in triplicate wells. ${ }^{*} T$ value between 0 and 5 (low level significance), ${ }^{* *} T$ value greater than 5 , but less than 10 (middle level significance), and ${ }^{* * *} T$ value greater than 10 (high level significance). MCE: T. esculentum bean cotyledon ethanolic extract, MSCE: $T$. esculentum bean husk ethanolic extract, MTW: T. esculentum tuber water extract, MSCW: T. esculentum bean husk water extract, MCW: T. esculentum bean cotyledon water extract, and Combivir: (lamivudine and zidovudine).

the whole 67 hours, coincubation of RV with bean seed coat extracts (ethanolic extract (MSCE), and water extract (MSCW) or AZT led to higher TER across the cells than when the virus was coincubated with cotyledon extracts (MCE and MCW). Incubation of $\mathrm{H} 4$ cells with individual extracts alone or AZT alone resulted in lower TER than extract/AZT-RV coincubation treatments. Incubation of cells with RV alone from the start of the experiment until about 40 hours resulted in TER lower than the rest of the treatments. However between 40 and 67 hours of exposure, wells with RV only treatments generally had higher TER (though sporadic) than the rest of the treatments. All T. esculentum extracts generally had better enhancement of TER than AZT over the initial 67 hours.

3.5. Exposure of Cells to T. esculentum Extracts Results in Variable Expression of NO from Human Intestinal Epithelial Cells (H4) and Pig Intestinal Epithelial Cells (CLAB). $\mathrm{NO}_{2}$ release was significant from human intestinal epithelial cells (H4) exposed to all extracts used sseed coat water and ethanolic extracts (MSCW and MSCE, resp.), cotyledon water and ethanolic extracts (MCW and MCE, resp.), and tuber water extract (MTW)\}, while only MCE and MTW significantly increased NO in CLAB cells (Figure 5).
3.6. Tylosema esculentum Extracts Inactivate Rotavirus. Results in Figure 6 show that pre-exposure to T. esculentum extracts can significantly reduce infectivity of RV. This finding broadly points to inhibition of RV cytopathic effect by $T$. esculentum extracts prior to or during virus entry (specific mechanisms were not determined). Exposure of $\mathrm{RV}$ (at $1 \times 10^{7.5} / \mathrm{mL} \mathrm{TCID}_{50}$ ) to T. esculentum extracts in vitro resulted in species-specific and variable protection of the intestinal epithelial cells used. Pretreatment of RV with T. esculentum cotyledon ethanolic and water extracts (MCE and MCW) led to highly significant ( $\left.{ }^{* * *} P \geq 10\right)$ survival of CIEB cells, while pretreatment of virus with MSCE also resulted in highly significant survival of CLAB cells. While pretreatment of RV with all T. esculentum extracts resulted in significant enhancement of all cell types used (CLAB, CIEB, and H4 cells), T. esculentum seed coat water extract (MSCW) significantly reduced cytopathic effects of RV at the lowest concentration $(0.001 \mathrm{mg} / \mathrm{mL})$, implying high potency of this extract. Additionally other extracts significantly reduced cytopathic effects of RV, namely, T. esculentum cotyledon extracts (MCE $1 \mathrm{mg} / \mathrm{mL}$ and $0.1 \mathrm{mg} / \mathrm{mL}$; MCW $2 \mathrm{mg} / \mathrm{mL}$ and $0.2 \mathrm{mg} / \mathrm{mL}$ ). There was species-specific improvement in cell survival by the extracts, mainly bovine intestinal epithelial (CIEB) showed the highest response to pretreatment of virus with extracts. 


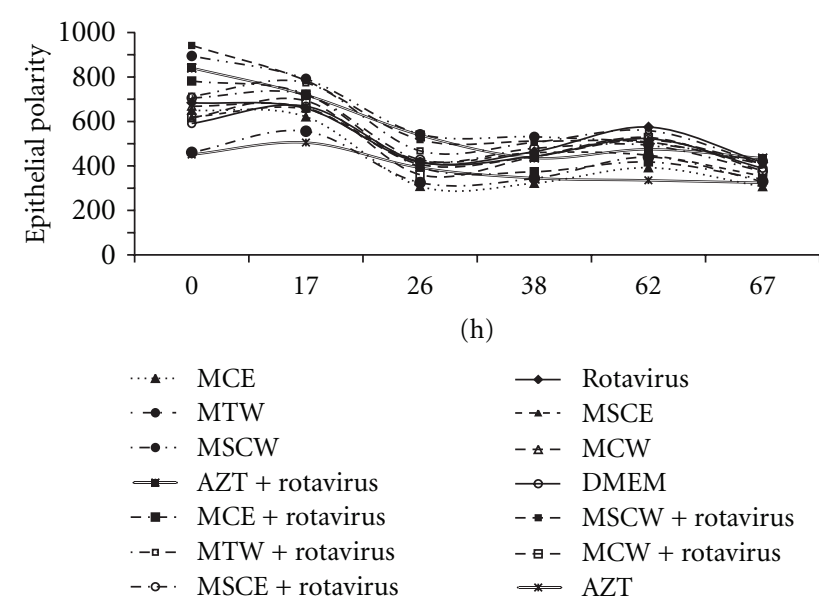

FIgURE 4: Effect of coincubation of rotavirus with T. esculentum extracts on monolayer polarity (TER) $\left(\Omega / \mathrm{cm}^{2}\right)$ of $\mathrm{H} 4$ cells over time. Shown graphs of change in epithelial cell monolayer polarity exposed to extracts or AZT and rotavirus (treatment wells), extracts or AZT alone (control), or rotavirus alone (negative control) over time compared to respective controls. Tests were done in triplicate wells (12-well Transwell plates). MCE: T. esculentum bean cotyledon ethanolic extract $(1 \mathrm{mg} / \mathrm{mL})$, MSCE: T. esculentum bean husk ethanolic extract $(0.1 \mathrm{mg} / \mathrm{mL})$, MTW: T. esculentum tuber water extract $(0.1 \mathrm{mg} / \mathrm{mL})$, MSCW: T. esculentum bean husk water extract $(0.01 \mathrm{mg} / \mathrm{mL}), \mathrm{MCW}$ : T. esculentum bean cotyledon water extract $(2 \mathrm{mg} / \mathrm{mL})$, and AZT: Combivir (lamivudine and zidovudine) $(0.75 \mathrm{mg} / \mathrm{mL})$.

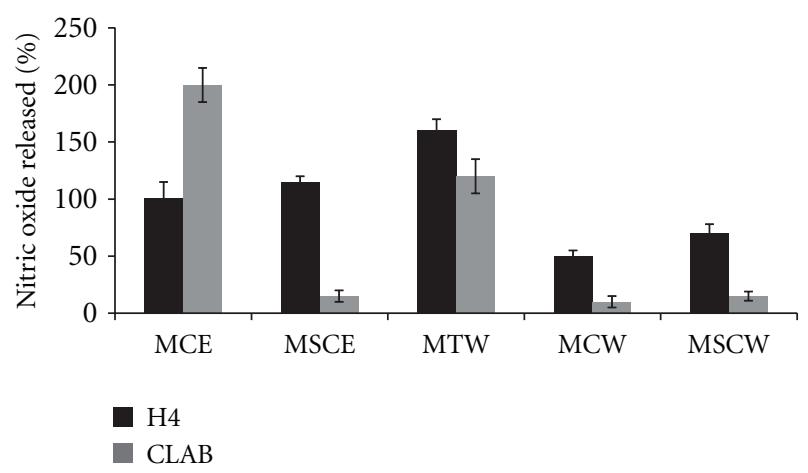

FIgURE 5: Effect of T. esculentum extracts on release of nitric oxide (NO) (\% release compared to control) in human small intestine epithelial cells (H4) and pig small intestine epithelial cells (CLAB). MCE: T. esculentum bean cotyledon ethanolic extract $(1 \mathrm{mg} / \mathrm{mL})$, MSCE: T. esculentum bean husk ethanolic extract $(0.1 \mathrm{mg} / \mathrm{mL})$, MTW: T. esculentum tuber water extract $(0.1 \mathrm{mg} / \mathrm{mL})$, MSCW: T. esculentum bean husk water extract $(0.01 \mathrm{mg} / \mathrm{mL})$, and MCW: T. esculentum bean cotyledon water extract $(2 \mathrm{mg} / \mathrm{mL})$.

3.7. Assessment of Correlation among T. esculentum and Antiviral Treatments. Table 3 shows correlation of antiviral effects of different treatments with T. esculentum extracts on different cell cultures. There was high positive correlation between CLAB and $\mathrm{H} 4$ cells $(r=0.94)$, moderately positive correlation between CLAB and CIEB cells $(r=0.57)$ in survival from rotavirus cytopathic effects after coincubation with T. esculentum extracts, while a weak negative correlation between $\mathrm{H} 4$ and CIEB cells $(r=-0.02)$ was observed after coincubation. Highly positive correlation between survival of CLAB cells after coincubation compared to preincubation with T. esculentum extracts $(r=0.91)$ and moderately positive correlation between CIEB cells pre- and coincubated with the extracts $(r=0.59)$ were observed. Poorly positive correlation between $\mathrm{H} 4$ cells co- and pretreated with the extracts was observed. Moderate positive correlations were also observed between survival of and nitric oxide release from CLAB $(r=0.43)$ and H4 cells $(r=0.79)$, as well as highly positive correlation in levels of nitric oxide release from $\mathrm{H} 4$ and CLAB cells $(r=0.9)$. Negative correlation was observed between survival rates and TER of cells (H4, CLAB and CIEB) after coincubation of rotavirus with T. esculentum extracts.

\section{Discussion}

We show herein that the RV strain used (RF strain) could be adapted to pig and human cells, additional to bovine cells. T. esculentum bean cotyledons had low or no cytotoxicity, as shown by high $\mathrm{IC}_{50}$ concentrations (Table 2; Figures 3 and 6), while seed coat and tuber extracts, especially seed coat ethanolic extract (MSCE) and tuber water extract (MTW), had elevated cytotoxic effects (low $\mathrm{IC}_{50}$ concentrations lying between 0.01 and $0.001 \mathrm{mg} / \mathrm{mL}$ ) on all the cells used (Table 2; Figures 3 and 6). This study has identified T. esculentum bean ethanolic cotyledon extract (MCE) and bean seed coat extract (MSCE) as having highly significant inhibitory effects against cytopathic effects of RV, both with coincubation (Figure 3) and preincubation (Figure 6) of the extracts and RV on human, pig, and bovine intestinal epithelial cells. Tylosema esculentum seed coat ethanolic extract (MSCE) showed the best antirotaviral activity, as shown by the lowest IC $_{50}$ concentrations $(1 \mu \mathrm{g} / \mathrm{mL})$.

Marama cotyledon ethanolic extract (MCE) offered similar and/or higher protection against cytopathic effects of RV than that offered by antiviral drug Combivir on all intestinal epithelial cells, with higher effect on CIEB and $\mathrm{H} 4$ cells. Exposure of CLAB cells to seed coat and cotyledon water and ethanolic extracts at concentrations lower than $\mathrm{IC}_{50}$ resulted in higher survival of the cells. This could be due to potentiated toxic effects due to combined presence of RV and extract (at $\mathrm{IC}_{50}$ concentration) and diluted cytotoxicity at lower extract concentrations. This effect was cell culture dependent, implying possible different interspecies responses.

There was positive correlation between levels of protection of intestinal cells from cytopathic effects of RV (crystal violet assay) with coincubation and preincubation and enhancement of polarity (TER) of H4, CLAB, and CIEB cells by T. esculentum extracts and Combivir (Table 3 ). Survival of CLAB and H4 cells was moderately to highly correlated to release of nitric oxide ( $r=0.79$ and $r=0.43$, resp.); similarly very high positive correlation was observed in levels of nitric oxide release from H4 and CLAB cells $(r=0.9)$ exposed to T. esculentum extracts (Table 3$)$. These findings show that there is a positive link between effects 


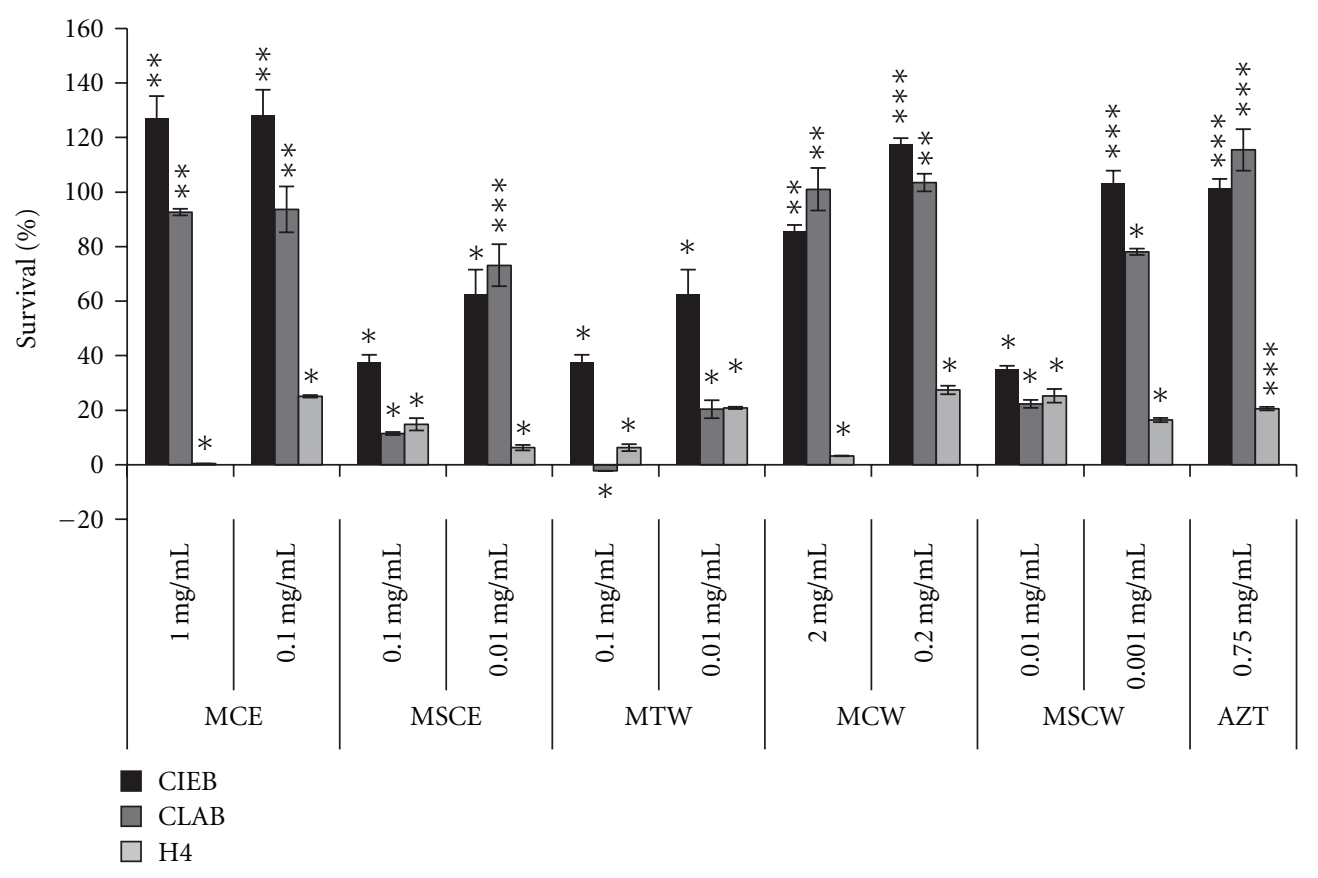

FIGURE 6: T. esculentum extracts show direct inhibition of rotavirus infectivity on bovine intestinal epithelial cells (CIEB), pig intestinal epithelial cells (CLAB), and human intestinal epithelial cells (H4). Shown above are bars of \% survival of epithelial cells $\{\%$ change in cell viability after pre-exposure of rotavirus to T. esculentum extracts compared to rotavirus only wells at OD $595 \mathrm{~nm} \pm \%$ standard deviation $\}$, respective levels of significance in terms of $T$ values $\left(^{*}\right)$. $T$ values were determined using Statsoft Statistica software $(P<.05)$. Tests were done in triplicate wells. ${ }^{*} T$ value between 0 and 5 (low level significance), ${ }^{* *} T$ value greater than 5 , but less than 10 (middle level significance), and ${ }^{* * *} T$ value greater than 10 (high level significance). MCE: T. esculentum bean cotyledon ethanolic extract, MSCE: T. esculentum bean husk ethanolic extract, MTW: T. esculentum tuber water extract, MSCW: T. esculentum bean husk water extract, MCW: T. esculentum bean cotyledon water extract, and AZT: Combivir (lamivudine and zidovudine).

of T. esculentum extracts (pre- and coincubated) against rotavirus on the different species of cells and the release of nitric oxide.

Coincubation of RV and marama seed coat ethanolic extract (MSCE), cotyledon ethanolic extract (MCE), or tuber water extract (MTW) on H4 cells resulted in generally higher enhancement of TER than Combivir throughout 67hour test period. Enhancement of polarity across intestinal epithelial cells can be an important mechanism to control entry of RV across the intestinal epithelial barrier. Rotaviruses are known to disrupt tight junctions, resulting in loss of transepithelial resistance (TER) [13], but without cell death during viral replication [35]; hence $T$. esculentum bean seed coat and cotyledon ethanolic extracts (MSCE and MCE, resp.) and T. esculentum tuber water extract (MTW) can reduce entry of RV across the intestinal barrier in vitro. Effects of T. esculentum extracts on transepithelial resistance of $\mathrm{H} 4$ cells, however, could not be linked to survival of $\mathrm{H} 4$ cells, as shown by negative correlation between survival of cells and TER in presence of the extracts.

Another mechanism of inhibition of RV by T. esculentum extracts, especially in seed coats, may lie in the inactivation of $\mathrm{RV}$, as shown with enhancement of cell survival after preincubation of rotavirus with $T$. esculentum extracts. It is herein suggested that the observed inactivation of $\mathrm{RV}$ may be through interference with either viral replication or capacity to bind to permissive cells. Clark et al. [36] have shown that some phenolic acids, which were expected to dominate the ethanolic extracts, have inactivation effect against RV. Similar observations were also made with extracts from peppermint, sage, and lemon balm leaves, which were highly inhibitive against HIV [37]. The inhibitive effects of T. esculentum extracts, especially seed coat and cotyledon ethanolic extract (MSCE and MCE) and tuber water extract (MTW) $(\geq 100 \%)$, could additionally be due to enhanced release of nitric oxide (NO) from intestinal cells. Nitric oxide has been shown to inactivate RV, mainly by inhibiting replication of the virus $[38,39]$. The observed enhancement of nitric oxide release from the human and pig cells was viewed as one of the mechanisms T. esculentum crude extracts can induce a nonspecific immune response in intestinal epithelium.

Certain plant phytochemicals have been shown to inhibit RV activity through inhibition of viral penetration and viral replication. Some flavonoids were shown to inhibit penetration of RV in rhesus monkey epithelial cell line (MA104) [31], while others have an effect on the viruses or on the enzymes responsible for their replication [40]. These effects could not be singly demonstrated in this study; further work on these possible mechanisms of antiviral effects of T. esculentum extracts is, therefore, encouraged. 
TABLE 3: Correlation analysis of antiviral effects of different treatments with T. esculentum extracts on different cell cultures.

Treatment

Correlation coefficient $(r)$

(a) Survival of $\mathrm{H} 4$ cells compared to CLAB cells from rotavirus effects with coincubation with

T. esculentum extracts

(b) Survival of H4 cells compared to CIEB cells from rotavirus effects with coincubation with

T. esculentum extracts

(c) Survival of CIEB cells compared to CLAB cells from rotavirus effects with coincubation with

T. esculentum extracts

(d) Survival of $\mathrm{H} 4$ cells from rotavirus effects with coincubation compared to preincubation with

T. esculentum extracts

(e) Survival of CLAB cells from rotavirus effects with coincubation compared to preincubation with

T. esculentum extracts

(f) Survival of CIEB cells from rotavirus effects with coincubation compared to preincubation with

T. esculentum extracts

(g) Survival from rotavirus effects of, compared to release of nitric oxide, CLAB cells with coincubation with

T. esculentum extracts

(h) Survival from rotavirus effects of, compared to release of nitric oxide from $\mathrm{H} 4$ cells after coincubation with

T. esculentum extracts

(i) Release of NO from $\mathrm{H} 4$ cells compared to CLAB cells after coincubation with

T. esculentum extracts

(j) Survival from rotavirus effects of, compared to TER, of H4 cells after coincubation with

T. esculentum extracts for $38 \mathrm{~h}$

(k) Survival from rotavirus effects of, compared to TER, of H4 cells after coincubation with

T. esculentum extracts for $62 \mathrm{~h}$

(1) Survival from rotavirus effects of, compared to TER, of H4 cells after coincubation with

T. esculentum extracts for $67 \mathrm{~h}$

The observed antirotaviral effects can be attributed to the high phenolic acid content (especially gallic acid), in bean cotyledons, among other components (Marama II report, unpublished). Gallic acid was previously shown to prevent viral replication, inhibition of virus attachment to and penetration into cells, and virucidal effects [41]. Interference with attachment and penetration into cells could not be proved in this study. Tylosema esculentum tubers may contain some yet to be determined phenolics (Marama II report, unpublished). Ethanolic extracts had notably higher antiviral activity than aqueous bean and tuber extracts (Figures 3 and 6). Some essential oils as found in T. esculentum beans may contribute towards the observed antiviral effects; similar findings were reported by Astani et al. [42] using essential oils extracted from Melaleuca alternifolia. Moreover, recently, a Kunitz-type inhibitor, distinct from other known plant serine protease inhibitors and shown to be specific for elastase, was isolated in T. esculentum beans [43]. The quantity of this elastase inhibitor present in T. esculentum beans is many times greater than in soybean or any other bean or nut source reported to date [43]. Certain protease inhibitors have been shown to impart high antienteroviral effects through interference with proteolytic cleavage during the replication process [44]. The high phytosterol content of T. esculentum bean oil 4-desmethylsterols (75\%) and 4.4-dimethylsterols and 4-monomethylsterols (15.72\%) [4] could also contribute to the high antiviral activity in bean extracts. Phytosterols have been determined to have antihuman cytomegalovirus (HCMV) and antiherpes simplex virus (HSV) effects [45]. The antiviral activity of phytosterols is through the blocking effect on immediate-early antigen expression in fibroblast cells and blocking of virus-cell interaction and/or virus multiplication [45].

Our results have shown high in vitro inhibition of RV by T. esculentum extracts, especially seed coat ethanolic extracts $(0.01$ to $0.001 \mathrm{mg} / \mathrm{mL})$ and cotyledon ethanolic extracts $(\geq 0.1 \mathrm{mg} / \mathrm{mL})$, and tuber water extract $(0.1$ to $0.01 \mathrm{mg} / \mathrm{mL})$. Mechanisms of antiviral action may include release of nitric oxide and may also interfere with viral cytopathic effects (as shown by moderate to high positive correlation between survival from rotavirus and release of nitric oxide), inactivation of RV (inhibition of virus replication or entry into cells may be responsible), possibly through interference with replication, and enhancement of tight junctions (though not directly related to levels of survival) (Figure 1). Our findings suggest that $T$. esculentum beans can be an important source of microbicides against RV. Further phytochemical characterization of T. esculentum extracts, identification of the responsible bioactive compounds, and the elucidation of other modes of action and quality standard studies are essential.

\section{Abbreviations}

MCE: Tylosema esculentum (marama) cotyledon ethanolic extract

MSCE: Tylosema esculentum (marama) seed coat ethanolic extract

MTW: Tylosema esculentum (marama) tuber water extract 
MCW: Tylosema esculentum (marama) cotyledon water extract

MSCW: Tylosema esculentum (marama) seed coat water extract

CLAB: Pig small intestine epithelial cell line

CIEB: Bovine small intestine epithelial cell line

H4: Human small intestine epithelial cell line

AZT: Combivir (lamivudine and zidovudine)

RV: Rotavirus

NO: Nitric oxide

TER: Transepithelial resistance.

\section{Conflict of Interests}

The authors declare that they have no competing interests.

\section{Acknowledgments}

This work was supported in part by grants from EU-INCO Marama II FP6 programme (contract number 032059). The authors also thank the technical team in Department of Chemistry, University of Botswana (A. Muzila, C. Ntwaagae, O. Oyentunji, O. Mazimba, Mrs E. Yeboah, and S. Ditlhabi) for providing the bean ethanolic extracts they used and for processing the tuber from which they obtained the water extracts and Ms Lidija Gradisnik (University of Maribor) for her wonderful technical support.

\section{References}

[1] L. J. G. van der Maesen, "T. esculentum (Burch.) A, Schreib," in PROTA 1: Cereals and Pulses, M. Brink and G. Belay, Eds., Wageningen, The Netherlands, PROTA, 2006.

[2] W. Chingwaru, M. L. Faria, C. Saravia, and A. Cencic, "Indigenous knowledge of Health Benefits of morama plant among respondents in Ghantsi and Jwaneng of Botswana," African Journal of Food, Agriculture, Nutrition and Development, vol. 7, no. 6, 2007.

[3] P. Buzzini, P. Arapitsas, M. Goretti et al., "Antimicrobial and antiviral activity of hydrolysable tannins," Mini-Reviews in Medicinal Chemistry, vol. 8, no. 12, pp. 1179-1187, 2008.

[4] Y. C. Mitei, J. C. Ngila, S. O. Yeboah, L. Wessjohann, and J. Schmidt, "Profiling of phytosterols, tocopherols and tocotrienols in selected seed oils from Botswana by GC-MS and HPLC," Journal of the American Oil Chemists' Society, vol. 86, no. 7, pp. 617-625, 2009.

[5] A. Andres, S. M. Donovan, T. B. Kuhlenschmidt, and M. S. Kuhlenschmidt, "Isoflavones at concentrations present in soy infant formula inhibit rotavirus infection in vitro," Journal of Nutrition, vol. 137, no. 9, pp. 2068-2073, 2007.

[6] S. Lecot, S. Belouzard, J. Dubuisson, and Y. Rouillé, "Bovine viral diarrhea virus entry is dependent on clathrin-mediated endocytosis," Journal of Virology, vol. 79, no. 16, pp. 1082610829, 2005.

[7] U. D. Parashar, J. S. Bresee, J. R. Gentsch, and R. I. Glass, "Rotavirus," Emerging Infectious Diseases, vol. 4, no. 4, pp. 561-570, 1998.

[8] U. D. Parashar, C. J. Gibson, J. S. Bresee, and R. I. Glass, "Rotavirus and severe childhood diarrhea," Emerging Infectious Diseases, vol. 12, no. 2, pp. 304-306, 2006.
[9] J. L. VanCott, M. A. Franco, H. B. Greenberg et al., "Protective immunity to rotavirus shedding in the absence of interleukin6: Th1 cells and immunoglobulin A develop normally," Journal of Virology, vol. 74, no. 11, pp. 5250-5256, 2000.

[10] S. H. Park, L. J. Saif, C. Jeong et al., "Molecular characterization of novel G5 bovine rotavirus strains," Journal of Clinical Microbiology, vol. 44, no. 11, pp. 4101-4112, 2006.

[11] S. D. Kelkar, A. B. Dindokar, G. B. Dhale, J. K. Zade, and S. S. Ranshing, "Culture adaptation of serotype G6 human rotavirus strains from hospitalized diarrhea patients in India," Journal of Medical Virology, vol. 74, no. 4, pp. 650-655, 2004.

[12] P. A. Maragkoudakis, W. Chingwaru, L. Gradisnik, E. Tsakalidou, and A. Cencic, "Lactic acid bacteria efficiently protect human and animal intestinal epithelial and immune cells from enteric virus infection," International Journal of Food Microbiology, vol. 141, supplement, pp. S91-S97, 2010.

[13] K. G. Dickman, S. J. Hempson, J. Anderson et al., "Rotavirus alters paracellular permeability and energy metabolism in Caco-2 cells," American Journal of Physiology - Gastrointestinal and Liver Physiology, vol. 279, no. 4, pp. G757-G766, 2000.

[14] G. Obert, I. Peiffer, and A. L. Servin, "Rotavirus-induced structural and functional alterations in tight junctions of polarized intestinal Caco-2 cell monolayers," Journal of Virology, vol. 74, no. 10, pp. 4645-4651, 2000.

[15] H. G. Chang, P. F. Smith, B. Tserenpuntsag, K. Markey, U. Parashar, and D. L. Morse, "Reduction in hospitalizations for diarrhoea and rotavirus infections in New York state following introduction of rotavirus vaccine," Vaccine, vol. 28, no. 3, pp. 754-748, 2009.

[16] T. Vesikari, R. Itzler, A. Karvonen et al., "RotaTeq, a pentavalent rotavirus vaccine: efficacy and safety among infants in Europe," Vaccine, vol. 28, no. 2, pp. 345-351, 2009.

[17] M. M. Cortese and U. D. Parashar, "Prevention of rotavirus gastroenteritis among infants and children: recommendations of the Advisory Committee on Immunization Practices (ACIP)," MMWR. Recommendations and Reports: Morbidity and Mortality Weekly Report, vol. 58, no. 2, pp. 1-25, 2009.

[18] D. F. Smee, R. W. Sidwell, and S. M. Clark, "Inhibition of rotaviruses by selected antiviral substances: mechanisms of viral inhibition and in vivo activity," Antimicrobial Agents and Chemotherapy, vol. 21, no. 1, pp. 66-73, 1982.

[19] R. E. C. Linhares, M. D. Wigg, M. H. C. Lagrota, and C. M. Nozawa, "The in vitro antiviral activity of isoprinosine on simian rotavirus (SA-11)," Brazilian Journal of Medical and Biological Research, vol. 22, no. 9, pp. 1095-1103, 1989.

[20] K. J. Clark, P. G. Grant, A. B. Sarr et al., "An in vitro study of theaflavins extracted from black tea to neutralize bovine rotavirus and bovine coronavirus infections," Veterinary Microbiology, vol. 63, no. 2-4, pp. 147-157, 1998.

[21] J. L. S. Gonçalves, R. C. Lopes, D. B. Oliveira et al., "In vitro anti-rotavirus activity of some medicinal plants used in Brazil against diarrhea," Journal of Ethnopharmacology, vol. 99, no. 3, pp. 403-407, 2005.

[22] B. W. Bolling and K. L. Parkin, "Limited contribution of isoflavones to hepatocellular phase II enzyme-inducing activity of soybean (Glycine max) extracts," Food Chemistry, vol. 113, no. 4, pp. 1069-1075, 2009.

[23] T. López, S. López, and C. F. Arias, "Heat shock enhances the susceptibility of BHK cells to rotavirus infection through the facilitation of entry and post-entry virus replication steps," Virus Research, vol. 121, no. 1, pp. 74-83, 2006. 
[24] O. A. Odunbaku, O. A. Illusanya, and K. S. Akasoro, "Antibacterial activity of ethanolic leaf extract of Ficus exasperata on Escherichia coli and Staphylococcus albus," Scientific Research and Essays, vol. 3, no. 11, pp. 562-564, 2008.

[25] I. R. Sanderson, R. M. Ezzell, M. Kedinger et al., "Human fetal enterocytes in vitro: modulation of the phenotype by extracellular matrix," Proceedings of the National Academy of Sciences of the United States of America, vol. 93, no. 15, pp. 7717-7722, 1996.

[26] L. Gradisnik, B. Filipic, C. de Vaureix, F. LeFevre, C. La Bonnardiere, and A. Cencic, "Establishment of a functional cell culture model of the pig small intestine," Alternativen $z u$ Tierexperimenten, vol. 23, no. 2, p. 94, 2006.

[27] S. Manta, E. Tsoukala, N. Tzioumaki et al., "Dideoxy fluoroketopyranosyl nucleosides as potent antiviral agents: synthesis and biological evaluation of 2,3- and 3,4-dideoxy-3-fluoro4 - and -2-keto- $\beta$-d-glucopyranosyl derivatives of $N^{4}$-benzoyl cytosine," European Journal of Medicinal Chemistry, vol. 44, no. 6, pp. 2696-2704, 2009.

[28] V. Enouf, P. Langella, J. Commissaire, J. Cohen, and G. Corthier, "Bovine rotavirus nonstructural protein 4 produced by Lactococcus lactis is antigenic and immunogenic," Applied and Environmental Microbiology, vol. 67, no. 4, pp. 1423-1428, 2001.

[29] L. J. Reed and H. Muench, "A simple method of estimating fifty per cent endpoints," American Journal of Epidemiology, vol. 27, no. 3, pp. 493-497, 1938.

[30] T. Botić, T. D. Klingberg, H. Weingartl, and A. Cencič, "A novel eukaryotic cell culture model to study antiviral activity of potential probiotic bacteria," International Journal of Food Microbiology, vol. 115, no. 2, pp. 227-234, 2007.

[31] E. A. Bae, M. J. Han, M. Lee, and D. H. Kim, "In vitro inhibitory effect of some flavonoids on rotavirus infectivity," Biological and Pharmaceutical Bulletin, vol. 23, no. 9, pp. 1122$1124,2000$.

[32] G. Agelis, N. Tzioumaki, T. Tselios, T. Botić, A. Cencič, and D. Komiotis, "Synthesis and molecular modelling of unsaturated exomethylene pyranonucleoside analogues with antitumor and antiviral activities," European Journal of Medicinal Chemistry, vol. 43, no. 7, pp. 1366-1375, 2008.

[33] G. Agelis, N. Tzioumaki, T. Botić, A. Cencič, and D. Komiotis, "Exomethylene pyranonucleosides: efficient synthesis and biological evaluation of 1-(2,3,4-trideoxy-2-methylene- $\beta$-dglycero-hex-3-enopyranosyl)thymine," Bioorganic and Medicinal Chemistry, vol. 15, no. 16, pp. 5448-5456, 2007.

[34] T. D. Klingberg, M. H. Pedersen, A. Cencic, and B. B. Budde, "Application of measurements of transepithelial electrical resistance of intestinal epithelial cell monolayers to evaluate probiotic activity," Applied and Environmental Microbiology, vol. 71, no. 11, pp. 7528-7530, 2005.

[35] K. G. Dickman, S. J. Hempson, J. Anderson et al., "Rotavirus alters paracellular permeability and energy metabolism in Caco-2 cells," American Journal of Physiology, vol. 279, no. 4, pp. G757-G766, 2000.

[36] K. J. Clark, P. G. Grant, A. B. Sarr et al., "An in vitro study of theaflavins extracted from black tea to neutralize bovine rotavirus and bovine coronavirus infections," Veterinary Microbiology, vol. 63, no. 2-4, pp. 147-157, 1998.

[37] M. A. Brindley, M. P. Widrlechner, J. A. McCoy et al., "Inhibition of lentivirus replication by aqueous extracts of Prunella vulgaris," Virology Journal, vol. 6, article no. 8, 2009.
[38] K. Akarid, M. Sinet, B. Desforges, and M. A. GougerotPocidalo, "Inhibitory effect of nitric oxide on the replication of a murine retrovirus in vitro and in vivo," Journal of Virology, vol. 69, no. 11, pp. 7001-7005, 1995.

[39] Y. L. Lin, Y. L. Huang, S. H. Ma et al., "Inhibition of Japanese encephalitis virus infection by nitric oxide: antiviral effect of nitric oxide on RNA virus replication," Journal of Virology, vol. 71, no. 7, pp. 5227-5235, 1997.

[40] W. Bylka, I. Matlawska, and N. A. Pilewskix, "Natural flavonoids as antimicrobial agents," Journal of American Nutraceutical Association, vol. 7, no. 2, pp. 24-31, 2004.

[41] J. M. Kratz, C. R. Andrighetti-Fröhner, D. J. Kolling et al., "Anti-HSV-1 and anti-HIV-1 activity of gallic acid and pentyl gallate," Memorias do Instituto Oswaldo Cruz, vol. 103, no. 5, pp. 437-444, 2008.

[42] A. Astani, J. Reichling, and P. Schnitzler, "Screening for antiviral activities of isolated compounds from essential oils," Evidence-Based Complementary and Alternative Medicine. In press.

[43] D. Nadaraja, S. T. Weintraub, K. W. Hakala, N. E. Sherman, and B. Starcher, "Isolation and partial sequence of a Kunitztype elastase specific inhibitor from marama bean (T. esculentum)," Journal of Enzyme Inhibition and Medicinal Chemistry, vol. 25, no. 3, pp. 377-382, 2010.

[44] A. G. Bukrinskaia, S. A. Kitsak VIa Moisiadi, and S. A. Arakelov, "Suppression of rotavirus SA-11 reproduction by protease inhibitors in cell culture," Voprosy Virusologii., vol. 32, no. 1, pp. 71-74, 1987.

[45] C. Eugster, G. Rivara, A. Biglino et al., "Phytosterol compounds having antiviral efficacy," Panminerva Medica, vol. 39, no. 1, pp. 12-20, 1997. 


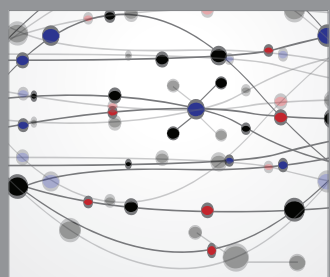

The Scientific World Journal
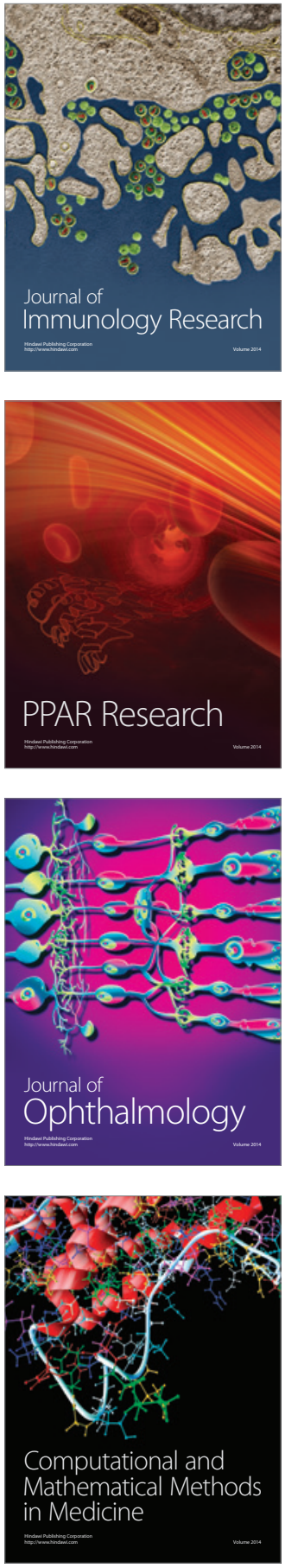

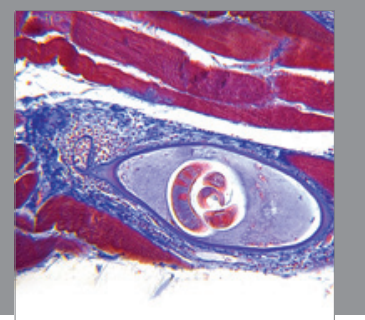

Gastroenterology

Research and Practice
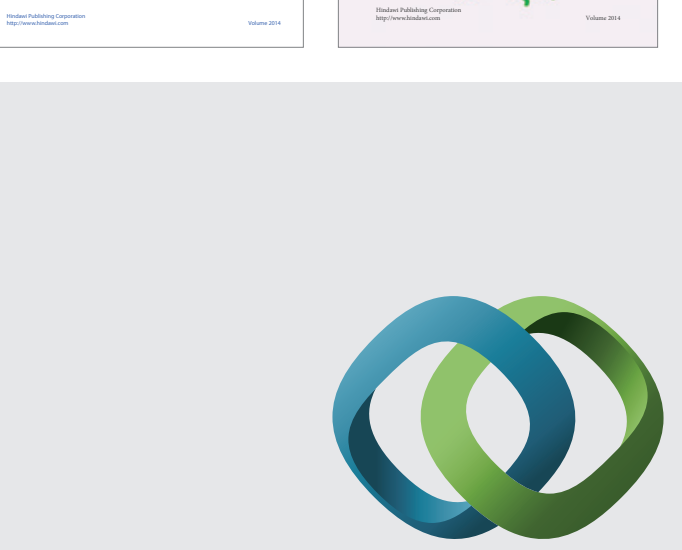

\section{Hindawi}

Submit your manuscripts at

http://www.hindawi.com
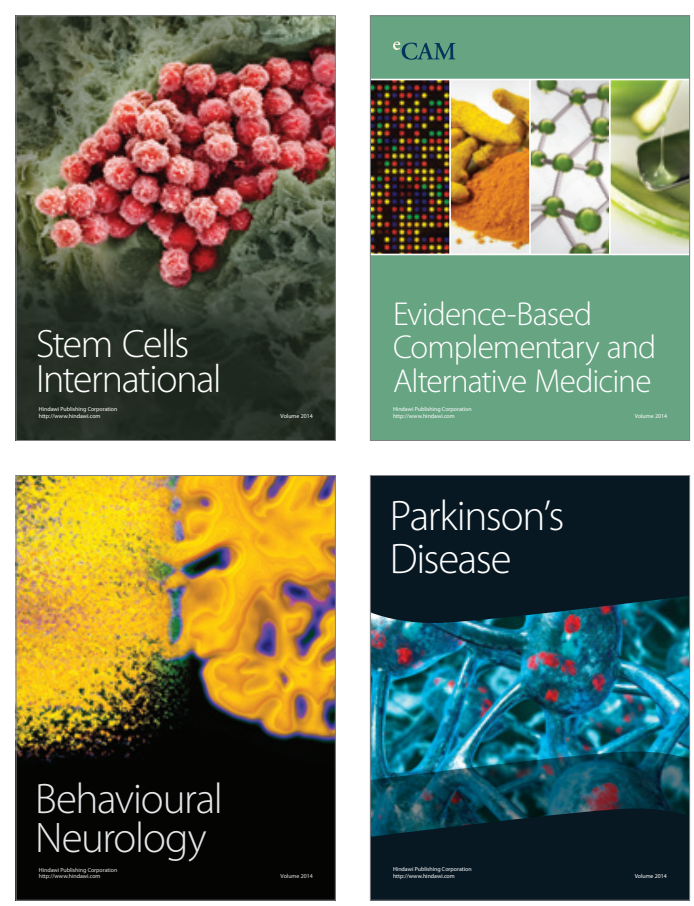

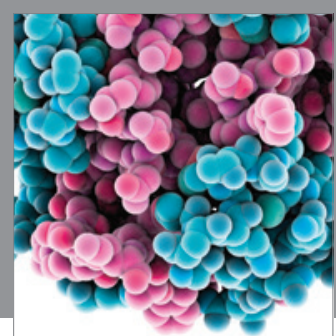

Journal of
Diabetes Research

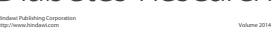

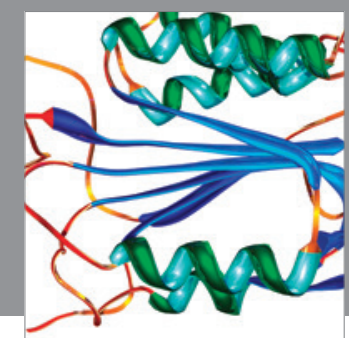

Disease Markers
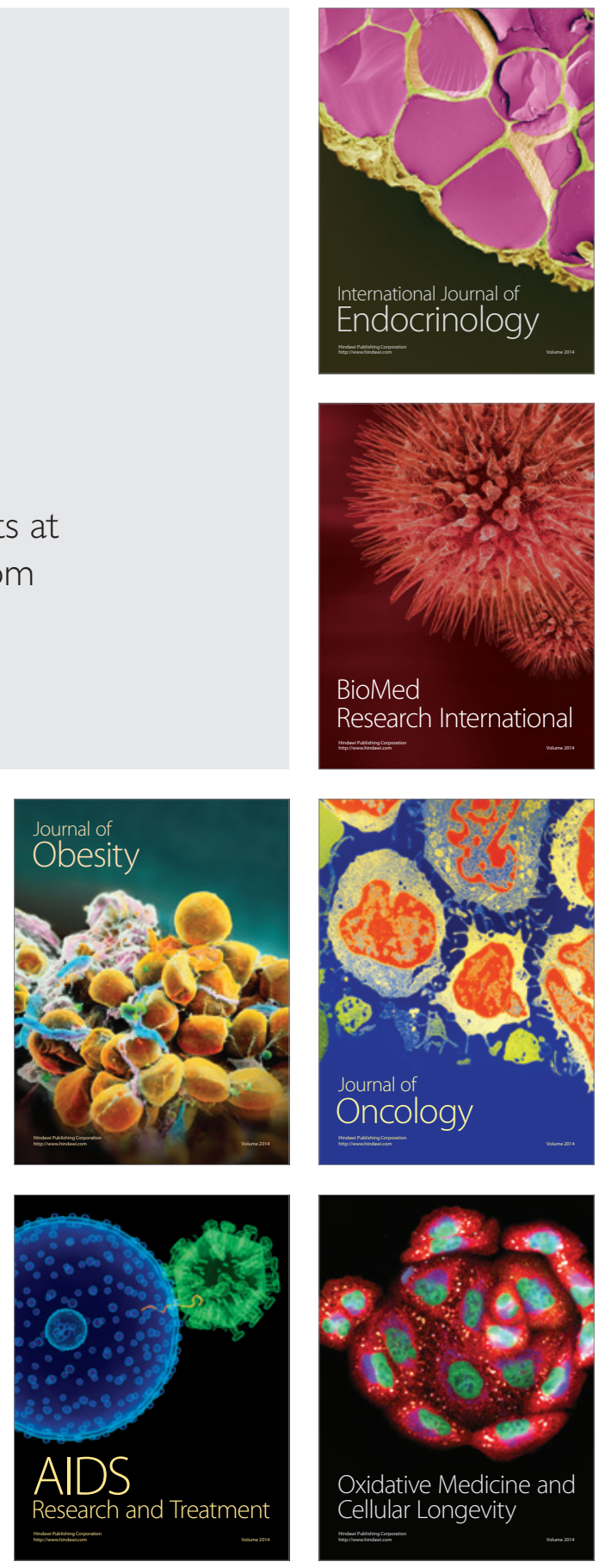